models that are sometimes mistaken for reality itself.

This kind of reflection will become more important as physics moves closer to achieving its aims of fundamental unification while simultaneously diverging into ever more disjointed sub-disciplines. The authors conclude with the statement that only if physics renounces its pretensions to be a perfect reflection of reality will it continue to thrive: "Its greatest challenge is to resist the temptation to project the false self-image of a religion able to reveal the ultimate truth". Its practitioners will do well to heed this advice. The book provides a helpful platform for reflection on such issues.

George Ellis is in the Mathematics Department,

University of Cape Town, Rondebosch 7700,

Cape Town, South Africa.

\section{ㄴ. \\ Heritable traits of a grandfather}

\section{Erasmus Darwin: A Life of \\ Unequalled Achievement}

by Desmond King-Hele

Giles de la Mare: 1999. 422 pp. 224.99 (pbk)

\section{W. F. Bynum}

To most people who have heard of him, Erasmus Darwin was a successful doctor, bad poet and, most significantly, the grandfather of Charles Darwin. In this astonishing book, Desmond King-Hele seeks to reverse the judgement and argue that Charles should rather be remembered as Erasmus's grandson. Erasmus, King-Hele concludes, was much the brighter spark, a genius of rare qualities. In this book, 'Darwinian' refers to the grandfather and his legacy.

I doubt if the meaning of the adjective will be changed as a result of the book, but KingHele's portrait of Dr Darwin is powerfully drawn. It is his sixth book, and second biography, devoted to his subject. The conclusions of his previous biography are unchanged, but the new availability of 170 family letters written by Darwin permits him to add much detail, including a valuable assessment of Darwin's relationship with his son (Charles's father), Robert Waring Darwin. Erasmus died before Charles was born, so the influence was through Robert Waring's recollections of his own father or through Erasmus's publications.

That Erasmus Darwin cut a substantial figure in his own lifetime cannot be doubted. Of massive size, with a pock-marked face and a severe stammer, he was also highly sexed and attractive to women. Following the death of his first wife, he sired two daughters by the servant looking after his young children. $\mathrm{He}$ then courted a beautiful, rich, married woman 16 years his junior, writing her love

\section{Erasmus courting}

Friend Boulton! Take these ingots fine From rich Potosi's sparkling mine; With your nice art a Tea-vase mould, Your art, more valu'd than the gold! With orient pearl, in letters white, Around it, 'To the Fairest', write; And where proud Radburn's turrets rise, To bright Eliza send the prize.

poetry (see above) when he was not busy tending her medical needs. After her husband conveniently died, the 50-year-old doctor won out over his younger rivals and had a further seven children by her.

Darwin's interesting domestic life did not get in the way of his medical practice. He was the pre-eminent practitioner in the industrializing Midlands, travelling as much as 10,000 miles a year around Nottingham, Lichfield and Derby, where he settled after his second marriage. No wonder he was concerned with the design of carriages and the building of canals.

For most of his life, his reputation was simply that of a good doctor (and genial host). His early publications were produced anonymously, Darwin fearing that general knowledge that he was an inventor, poet, industrial entrepreneur and botanist would make patients less likely to consult him. Nor was he especially good at exploiting his mechanical ingenuity. His copying machine went unpatented, as did his ingenious improvements to the steering mechanism and springs of his carriage. His designs for a steam carriage or his speculations about mechanized flight were confined to his private commonplacebook or to correspondence with close friends. Among the latter were many of the pioneers of the Industrial Revolution, including James Watt, Matthew Boulton and Josiah Wedgwood. Making and keeping friends were two of his most endearing and enduring traits.

The necessity of earning his living through practising medicine thus rendered Darwin a behind-the-scenes figure in both the Industrial Revolution and the world of letters. Only in his last decade, the 1790s, did he venture to come into the limelight. First came his long, two-part scientific poem, The Botanic Garden. This was followed by a massive synthesis of medical knowledge (Zoonomia), further scientific poetry, a prose work on botany and scientific agriculture, and an essay on female education. This last was written for his two illegitimate daughters, whom he had set up as proprietresses of a boardingschool for young women. Altogether, he published more than a million words, not bad for a busy doctor chary of print.

Nor was the quality of his insight swamped by the quantity of words he scribbled. King-Hele reckons he contributed insight to no fewer than 86 areas of human endeavour and knowledge, ranging from adi- abatic expansion to weather maps, from artesian wells to water closets. His ideas about evolution were based on an appreciation of the significance of the fossil record, the reality of biological extinction and the immense age of the Earth. He also remarked that the first law of organic nature was expressed in the words, "Eat or be eaten". Why, then, is the 'Darwin industry' confined almost exclusively to the grandson, especially when evolution and survival of the fittest are among those areas of grandfatherly insight?

There are a number of reasons. Many of his best ideas and inventions lay hidden in his commonplace-book until long after his death. Then, too, poetry is not the usual way to expound scientific discovery, at least not in the modern world. Even Darwin's reputation as a major poet was short-lived. Despite his undeniable influence on the Romantic poets, Darwin was soon relegated to the stilted and formal versifiers of the earlier age. His poetry is easier to admire than to respond to. Nor did his evolutionary ideas, deism and sympathy for the French Revolution endear him to the conservative thinkers and politicians who dominated British life after the Terror.

But if Darwin's historical fortunes have not been all he deserved, he has at least been fortunate in his modern biographer. Like Darwin himself, King-Hele is both a poet and a Fellow of the Royal Society, and his sympathy for his subject is total. Few scientific lives have ever been so carefully and thoughtfully examined. There are no final words in history, but this is a biography for which the word definitive can be aptly applied. I just wish I liked Darwin's poetry more.

W. F. Bynum is at the Wellcome Institute for the History of Medicine, 183 Euston Road, London NW1 2BE, UK.

\section{An economist's use for sand}

\section{The Ostrich Factor: Our Population Myopia \\ by Garrett Hardin \\ Oxford University Press: 1999. 176 pp. £15.95, \$22}

\section{Paul Demeny}

Readers familiar with Garrett Hardin's extensive works will pick up this slim volume confident of a re-encounter with his longrehearsed themes on population growth and its dire effects. In this they will not be disappointed. As the ornithological title of the book suggests, the message this time is delivered with amplified polemical verve. Economists, we are told, are ostrich-like: they deny that a population problem exists. They disregard the limits on resources that nature imposes on man. They are unaware of the 


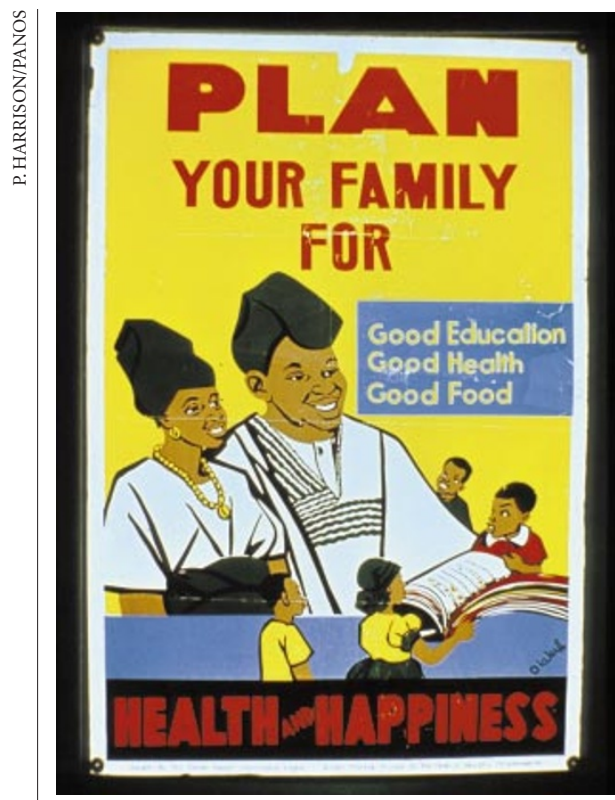

Curbing growth: there has been a marked ...

power of human reproductive capacity, and have wrong ideas on such matters as free trade, multiculturalism and immigration (they tend to favour them all). Hardin's message to them is distilled in pithy admonitions, such as: "Thou shalt not transgress the carrying capacity"; "the maximum is not the optimum"; and "sustainable growth is an oxymoron".

Whatever the merits of the arguments in support of such aphorisms, they suffer here from brevity. Hardin's 1993 book, Living Within Limits (Oxford University Press), addressed the same topics with a combativeness tempered with documentary detail, which is in very short supply here. On the book's dust-jacket, the reader is promised "an uncompromising critique of mainstream economic thinking". Coming from an eminent biologist that should be a bonus. Disappointingly, Hardin's commentary displays a disconcerting lack of familiarity with economics - not a good basis for interdisciplinary dialogue.

Hardin's penchant for citing and interpreting past, often ancient, thinkers to shed light on contemporary issues is delightful. But economists, even those long defunct, do not seem to have figured much on his reading list. He complains, for instance, that they do not use the word 'environment'. Take, he says, John Stuart Mill's Principles of Political Economy (1848): the word is not in its index. But, arguably, no one in the past century and a half has written more eloquently about the desirable balance between man and nature than did, in Book IV, Chapter 6 of that work, Mill.

Today's "ostriches" are even less appreciated by Hardin. He sees them as possessed by growth mania - they are heedless maximizers. Yet economists' maximizing is based on a belief that what people maximize is utility subject to constraints: more of something must always be balanced against the value of what has to be given up as its price. Economists also insist that voluntary exchanges between people are value-creating acts: they benefit both parties. But Hardin thinks they are a zero-sum game: what one acquires the other loses. Thus, he claims - in the face of massive evidence to the contrary - that free trade is a menace to material betterment.

Like many biologists, he sees man as just another animal species, and so underestimates the human potential for intelligent responses to environmental change, material scarcity and deficiencies in social arrangements. Economists do know that entities with a physical component cannot grow for ever. However, they recognize that there is no point in projecting exponential increase into the indefinite future because humans' economic calculations should provide corrective action to continuing population growth long before T. R. Malthus's pestilence and vice come into play.

A debate of the issue would require a close look at contemporary demographic trends, which Hardin fails to take. Examination of the evidence would reveal that the extraordinarily rapid expansion in the size of the human population during the past half-century was driven by a fall in death rates - by most evaluations, but not necessarily Hardin's, a positive development. It would also show that there has been a major and apparently accelerating downward adjustment of fertility rates in the past quarter-century. As a result, population growth rates have been falling. Standard projections see a levelling-off at 8 or 9 billion, plausibly followed by a declining population size.

Hardin offers a page of citations from assorted contemporary ostriches revealing their myopia by discounting the importance of limits on our natural resources and by expecting that living standards will continue to improve. It would be fair to say that the lack of alarm reflected in those citations is based on the perception that the declining curve of demographic growth is a natural outcome of the continuing structural transformations in the world economy. As the terms of the economic calculus guiding reproductive decisions shift, 'utility-maximizing' individuals will choose to restrict their fertility.

That the outcome of this process is desirable, however, is far from assured. The result of this interaction of utility-maximizing individuals may not deliver demographic patterns that the individual may consider best. As every member of society has an interest in the demographic behaviour of others, it may be possible to change the social rules of the game affecting such behaviour to the benefit of all. The merit of this book, and of Hardin's past work, is that it draws attention to this possibility and to the paucity of discussion surrounding the issue.

Ironically, future manifestations of such market failures are more likely to have the opposite effect to the one that concerns Hardin, namely, that individual demographic choices may result in fertility levels that are well below the rate of replacement, and will produce a rapid decline in population and population ageing. But at present the reverse pattern can still be a problem. The economist's remedy (systemic and structural, through market-orientated development) and the complementary programmatic approach (better reproductive services, education, empowerment of women) are prescriptions that can command wide consensus. However, sometimes, and in some places, they may act too slowly. Hardin thinks this and calls for draconian solutions. An attempt to offer specific advice on the matter was indeed the original motive for this book. In past work, he says, "I was inhibited by unacknowledged taboos against taking a Darwinian approach to population. ... At the risk of coming a cropper, I approach the Malthusian barrier once more.”

And what advice do we receive? "The first thing to do would be to cancel income deductions for the third child in a family (and beyond). If that is accepted ... we can think about stronger measures." - End of prescription. The image of the paterfamilias in, say, Rwanda, filling out his tax form and worrying about his deductions is too bizarre to contemplate. Perhaps another book is needed, approaching the Malthusian barrier once more. Or perhaps the absence of a better prescription simply shows that any "repressive legal measures" for reducing fertility come at a cost that is unacceptable to a democratic society. Muddling through with the known, ifless than perfect, remedies is preferable.

Paul Demeny is at the Population Council, One Dag Hammarskjold Plaza, New York, New York 10017, USA.

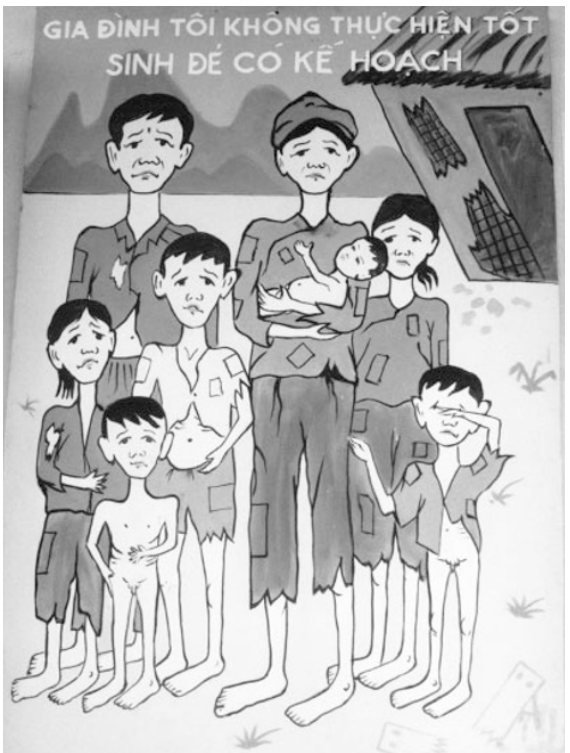

... decline in fertility rates in the past 25 years. 